\title{
WŁAŚCIWOŚĆ RZECZOWA REGIONALNYCH IZB OBRACHUNKOWYCH JAKO ORGANÓW NADZORU WOBEC JEDNOSTEK SAMORZĄDU TERYTORIALNEGO A ZAKRES POJĘCIA „SPRAWY FINANSOWE” - PRÓBA UPORZĄDKOWANIA PROBLEMATYKI
}

\section{Wstęp}

W świetle samorządowych ustaw ustrojowych do organów nadzoru nad jednostkami samorządu terytorialnego zarówno gminnego, powiatowego, jak i samorządu województwa należą Prezes Rady Ministrów, wojewoda, a w zakresie spraw finansowych - regionalna izba obrachunkowa (dalej: RIO) ${ }^{1}$. Takie samo sformułowanie zastosowane zostało również w Konstytucji RP z 1997 r. ${ }^{2}$ O ile uprawnienia nadzorcze Prezesa Rady Ministrów mają charakter wyjątkowy i występują wyłącznie w sytuacjach wskazanych w przepisach ustaw ustrojowych ${ }^{3}$, o tyle uprawnienia

* Dr, Uniwersytet Szczeciński; e-mail: wioleta.baranowska-zajac@usz.edu.pl, https:/ / orcid.org/0000-0002-1175-9739.

1 Zob. art. 86 ustawy z dnia 8 marca 1990 r. o samorządzie gminnym, tekst jednolity: Dz. U. z 2020 r. poz. 713; art. 76 ust. 1 ustawy z dnia 5 czerwca 1998 r. o samorządzie powiatowym, tekst jednolity: Dz. U. z 2020 r. poz. 920; art. 78 ust. 1 ustawy z dnia 5 czerwca 1998 r. o samorządzie województwa, tekst jednolity: Dz. U. z 2019 r. poz. 512 z późn. zm. (dalej łącznie: samorządowe ustawy ustrojowe).

2 Zob. art. 171 ust. 2 Konstytucji Rzeczypospolitej Polskiej z dnia 2 kwietnia 1997 r., Dz. U. poz. 483 z późn. zm. (dalej: Konstytucja RP).

3 Do uprawnień tych należą zawieszenie, na wniosek ministra właściwego do spraw administracji publicznej, w razie nierokującego nadziei na szybką poprawę i powtarzającego się braku skuteczności w wykonywaniu zadań publicznych, organów jednostki samorządu terytorialnego i ustanowienia zarządu komisarycznego na okres do dwóch lat (art. 97 ustawy z dnia 8 marca 1990 r. o samorządzie gminnym, art. 84 ustawy z dnia 5 czerwca 1998 r. o samorządzie powiatowym oraz art. 85 ustawy z dnia 5 czerwca 1998 r. 
nadzorcze wojewody i RIO uznaje się zasadniczo za równoważne ${ }^{4}$. Różnica $\mathrm{w}$ sprawowaniu nadzoru nad jednostkami samorządu terytorialnego przez wojewodów oraz przez RIO sprowadza się jednak do tego, że te ostatnie wykonują go „w zakresie spraw finansowych". Pojęcie "spraw finansowych" stanowi zatem kryterium odróżniające nadzór sprawowany przez wojewodów oraz przez RIO, a tym samym zakreślające granice właściwości rzeczowej RIO w zakresie tego nadzoru. Pojęcie to nie zostało przy tym zdefiniowane $\mathrm{w}$ treści przepisów samorządowych ustaw ustrojowych. Jednoznaczna definicja nie wynika także z ustawy o regionalnych izbach obrachunkowych ${ }^{5}$. W ustawie posłużono się natomiast wskazaniem właściwości rzeczowej RIO w stosunku do działalności nadzorczej wobec jednostek samorządu terytorialnego. Zakres pojęcia "spraw finansowych" ustalany w orzecznictwie sądów administracyjnych, a także w praktyce stosowania prawa wydaje się przy tym szerszy niż zakres właściwości RIO w obszarze ich działalności nadzorczej wobec jednostek samorządu terytorialnego wskazany w ustawie o regionalnych izbach obrachunkowych ${ }^{6}$.

Celem niniejszego opracowania jest analiza stosunku zakresu właściwości rzeczowej RIO w obszarze działalności nadzorczej wobec jednostek samorządu terytorialnego do zakresu pojęcia "spraw finansowych", wynikającego z przepisów o nadzorze zawartych w Konstytucji RP oraz w samorządowych ustawach ustrojowych, jako zastosowanego przez

\footnotetext{
o samorządzie województwa), wnioskowanie do Sejmu o rozwiązanie organu stanowiącego jednostki samorządu terytorialnego oraz rozwiązanie zarządu - w powiecie i województwie - a także odwołanie wójta, burmistrza lub prezydenta miasta - w gminie - w razie powtarzającego się naruszania przez dany organ Konstytucji lub ustaw (art. 96 ustawy z dnia 8 marca 1990 r. o samorządzie gminnym, art. 83 ustawy z dnia 5 czerwca 1998 r. o samorządzie powiatowym oraz art. 84 ustawy z dnia 5 czerwca 1998 r. o samorządzie województwa).

4 Zob. H. Izdebski, Samorząd terytorialny. Podstawy ustroju i działalności, wyd. 3, Warszawa 2014, s. 442; por. też J. Storczyński, Nadzór regionalnej izby obrachunkowej nad samorzadem terytorialnym, Bydgoszcz-Chorzów 2006.

5 Ustawa z dnia 7 października 1992 r. o regionalnych izbach obrachunkowych, tekst jednolity: Dz. U. z 2019 r. poz. 2137.

6 Przed nowelizacją z dnia 11 kwietnia 2001 r. ustawy z dnia 8 marca 1990 r. o samorządzie gminnym posługiwała się $\mathrm{w}$ analizowanym obszarze pojęciem o węższym zakresie przedmiotowym „nadzoru w zakresie spraw budżetowych”, zob. D.R. Kijowski, System nadzoru nad samorzadem terytorialnym w świetle ustawy z 8 marca 1990 r., Państwo i Prawo 1990, z. 12, s. 5; B. Dolnicki, w: Ustawa o samorzadzie gminnym. Komentarz, red. B. Dolnicki, Warszawa 2016, s. 1112.
} 
ustawodawcę kryterium odróżniającego zakres nadzoru nad jednostkami samorządu terytorialnego sprawowanego przez wojewodów oraz przez RIO. Z uwagi na to, że zakres uprawnień nadzorczych wojewody i RIO jest zasadniczo tożsamy i obejmuje stwierdzanie nieważności uchwał lub zarządzeń organów jednostek samorządu terytorialnego w przypadku istotnego naruszenia przez nie przepisów prawa oraz stwierdzanie ich wydania $\mathrm{z}$ naruszeniem prawa $\mathrm{w}$ razie nieistotnej tego rodzaju sprzeczności oraz ze względu na to, że w orzecznictwie sformułowano pogląd, zgodnie z którym wojewoda nie jest właściwy w orzekaniu w sprawie nieważności uchwał, co do których właściwa jest $\mathrm{RIO}^{7}$, istotne staje się precyzyjne ustalenie zakresu działania RIO, a tym samym rozgraniczenie kompetencji nadzorczych dwóch wskazanych organów nadzoru nad jednostkami samorządu terytorialnego.

Ustalenie znaczenia terminu "sprawy finansowe”, a ściślej - sposobu rozumienia jego zakreślenia dokonanego przez ustawodawcę - było przedmiotem uwagi doktryny, jak również orzecznictwa sądów administracyjnych. Jak dotąd nie wypracowano jednak w tym zakresie spójnej koncepcji ${ }^{8}$. Pomimo 25-letniej tradycji funkcjonowania RIO w Polsce i kilkukrotnych nowelizacji ustawy o regionalnych izbach obrachunkowych w tej materii ${ }^{9}$ jednoznaczne wskazanie zakresu ich właściwości w odniesieniu do nadzoru sprawowanego wobec jednostek samorządu terytorialnego wciąż nastręcza trudności.

7 Wyrok Naczelnego Sądu Administracyjnego (dalej: NSA) z dnia 5 marca 2002 r., II SA/Ka 3232/01, Orzecznictwo w Sprawach Samorządowych 2002, nr 3, poz. 88.

8 Sądy administracyjne reprezentowały dwie koncepcje dotyczące określenia zakresu pojęcia „sprawa budżetowa” przed nowelizacją ustawy z dnia 7 października $1992 \mathrm{r}$. o regionalnych izbach obrachunkowych z 1997 r. - w myśl koncepcji rozszerzającej uważano, że zakres nadzoru określony w art. 11 z dnia 7 października 1992 r. o regionalnych izbach obrachunkowych nie ma charakteru wyczerpującego - tak w wyroku NSA z dnia 9 października 1996 r., SA/Bk/95 oraz w postanowieniu NSA z dnia 26 sierpnia 1994 r., SA/Wr 1061/94. Natomiast w świetle koncepcji zawężającej przyjętej przez niektóre sądy pojęcie "sprawa budżetowa” należy rozumieć wąsko - tak w wyrokach NSA z dnia 12 grudnia 1995 r., SA/Po 1525/95 oraz z dnia 15 lutego 1996 r., SA/Po 3073/95.

9 Nowelizacje te zostały przeprowadzone w roku 1997, 1998 oraz 2000, zob. R.P. Krawczyk, Efektywność i skuteczność nadzoru nad samorzadem terytorialnym a uwarunkowania prawno-faktyczne, Finanse Komunalne 2014, t. 21, nr 10, s. 7; J. Glumińska-Pawlic, Czy nadzór i kontrola nad gospodarka finansowa jednostek samorzadu terytorialnego ograniczaja ich samodzielność?, w: Samorząd - Finanse - Nadzór i kontrola. XX-lecie Regionalnych Izb Obrachunkowych, red. R.P. Krawczyk, M. Stec, Warszawa 2013 [wyd. el. LEX]. 


\section{RIO w systemie organów nadzoru nad jednostkami samorządu terytorialnego}

Zgodnie z dyspozycją art. 1 ust. 1 ustawy o regionalnych izbach obrachunkowych RIO są państwowymi organami nadzoru i kontroli gospodarki finansowej $\mathrm{w}$ zakresie działalności podmiotów samorządowych wskazanych w art. 1 ust. 2 pkt 1-7 tej ustawy.

Pozycja prawno-ustrojowa RIO została określona w Konstytucji RP, która przewiduje w art. 171, że izby sprawują nadzór nad działalnością samorządu terytorialnego w zakresie spraw finansowych. Szczegółowe określenie zakresu działania izb znajduje się w ustawie o regionalnych izbach obrachunkowych. W myśl przepisów tej ustawy RIO sprawują nadzór nad działalnością jednostek samorządu terytorialnego w zakresie spraw finansowych oraz dokonują kontroli gospodarki finansowej i zamówień publicznych. Podmiotami samorządowymi, które podlegają nadzorowi izb, są jednostki samorządu terytorialnego, związki metropolitalne, związki międzygminne, stowarzyszenia gmin, stowarzyszenia gmin i powiatów, związki powiatów, związki powiatowo-gminne, stowarzyszenia powiatów, samorządowe jednostki organizacyjne, w tym samorządowe osoby prawne oraz inne podmioty $\mathrm{w}$ zakresie wykorzystywania przez nie dotacji pochodzących z budżetów jednostek samorządu terytorialnego ${ }^{10}$. Zadania izb wynikają nie tylko z ustawy o regionalnych izbach obrachunkowych, ale i ustawy o finansach publicznych ${ }^{11}$ oraz innych aktów prawnych ${ }^{12}$.

Z Konstytucji RP oraz z samorządowych ustaw ustrojowych wynika, że RIO sprawują nadzór nad działalnością samorządu terytorialnego w zakresie spraw finansowych z punktu widzenia kryterium legalności. $\mathrm{W}$ toku prowadzonego postępowania nadzorczego kolegium izby ${ }^{13}$ orze-

10 Art. 1 ust. 2 pkt 1-7 ustawy z dnia 7 października 1992 r. o regionalnych izbach obrachunkowych, por. T. Dobek, Działalność regionalnych izb obrachunkowych w 2016 r. Omówienie sprawozdania Krajowej Rady Regionalnych Izb Obrachunkowych złożonego do Sejmu i Senatu Rzeczypospolitej Polskiej, Finanse Komunalne 2017, t. 24, nr 7-8, s. 126.

11 Ustawa z dnia 27 sierpnia 2009 r. o finansach publicznych, tekst jednolity: Dz. U. z 2019 r. poz. 869 z późn. zm.

12 Zob. T. Dobek, Działalność regionalnych izb obrachunkowych..., s. 126; Regionalne izby obrachunkowe. Charakterystyka ustrojowa i komentarz do ustawy, red. M. Stec, Warszawa 2010 [wyd. el. LEX].

13 Zob. art. 18 ust. 1 pkt 1 ustawy z dnia 7 października 1992 r. o regionalnych izbach obrachunkowych. 
ka o nieważności uchwał i zarządzeń sprzecznych z prawem. W przypadku gdy naruszenie jest nieistotne, ogranicza się do wskazania, że uchwała bądź zarządzenie zostały podjęte $\mathrm{z}$ naruszeniem prawa ${ }^{14}$.

Wszczynając postępowanie $\mathrm{w}$ sprawie stwierdzenia nieważności uchwały lub zarządzenia, izba może wstrzymać ich wykonanie ${ }^{15}$, a po upływie 30 dni od dnia doręczenia uchwały lub zarządzenia izba nie może już we własnym zakresie stwierdzić nieważności uchwały lub zarządzenia organu jednostek samorządu terytorialnego, może jednak zaskarżyć taką uchwałę lub zarządzenie do sądu administracyjnego ${ }^{16}$. Po upływie roku od daty podjęcia kwestionowanej uchwały lub zarządzenia nie stwierdza się ich nieważności, chyba że nie zostały one przedłożone izbie $\mathrm{w}$ terminie siedmiu dni od daty ich podjęcia. $W$ tej ostatniej sytuacji zatem, jeśli istnieją przesłanki do stwierdzenia nieważności uchwały lub zarządzenia, to nawet po upływie rocznego terminu uprawniony organ orzeka o ich niezgodności z prawem ${ }^{17}$.

Szczególny tryb postępowania dotyczy stwierdzenia nieważności całości lub części uchwały budżetowej. W takim przypadku, jeżeli wskazane przez izbę nieprawidłowości w treści uchwały nie zostaną usunięte w wyznaczonym terminie, kolegium izby orzeka o nieważności uchwały w części lub całości i ustala budżet lub jego nieważną częśćc ${ }^{18}$. W sytuacji nieuchwalenia budżetu przez organ stanowiący jednostkę samorządu terytorialnego $\mathrm{w}$ terminie do 31 stycznia roku budżetowego ustawa o finansach publicznych nakłada na izbę obowiązek ustalenia budżetu do końca lutego w zakresie zadań własnych oraz zadań zleconych. Ponadto

14 Zob. art. 11 ust. 3 ustawy z dnia 7 października 1992 r. o regionalnych izbach obrachunkowych.

15 Art. 91 ust. 2 ustawy z dnia 8 marca 1990 r. o samorządzie gminnym, art. 79 ust. 2 ustawy z dnia 5 czerwca 1998 r. o samorządzie powiatowym, art. 82 ust. 2 ustawy z dnia 5 czerwca 1998 r. o samorządzie województwa.

16 Art. 93 ust. 1 w zw. z art. 91 ust. 1 ustawy z dnia 8 marca 1990 r. o samorządzie gminnym, art. 81 ust. 1 w zw. z art. 79 ust. 1 ustawy z dnia 5 czerwca 1998 r. o samorządzie powiatowym, art. 82c ust. $1 \mathrm{w}$ zw. z art. 82 ust. 1 ustawy z dnia 5 czerwca 1998 r. o samorządzie województwa.

17 Zob. art. 94 ust. 1 i ust. 2 ustawy z dnia 8 marca 1990 r. o samorządzie gminnym, art. 82 ust. 1 i ust. 2 ustawy z dnia 5 czerwca 1998 r. o samorządzie powiatowym, art. 83 ust. 1 i ust. 2 ustawy z dnia 5 czerwca 1998 r. o samorządzie województwa.

18 Zob. art. 12 ust. 1-3 ustawy z dnia 7 października 1992 r. o regionalnych izbach obrachunkowych. 
w sytuacjach wskazanych $\mathrm{w}$ przepisach art. $240 \mathrm{a}^{19} \mathrm{i}$ art. $240 \mathrm{~b}^{20}$ ustawy z o finansach publicznych RIO ustalają budżety jednostek samorządu terytorialnego $\mathrm{w}$ związku z naruszeniem zasad określonych $\mathrm{w}$ przepisach art. 242-244 tej ustawy ${ }^{21}$.

Ze względu na to, że uchwały budżetowe obowiązują przez okres roku kalendarzowego, nieuzasadnione jest orzekanie o ich nieważności, jeżeli w chwili orzekania uchwały te utraciły już moc obowiązującą. W takim przypadku należy orzec jedynie o ich niezgodności z prawem, bowiem nie ma sensu wyznaczanie terminu usunięcia nieprawidłowości, jeżeli organy jednostek samorządu terytorialnego nie mogą już podjąć prawidłowej uchwały zmieniającej ${ }^{22}$. Uchwała taka nie wykazuje cech rozstrzygnięcia nadzorczego $\mathrm{w}$ rozumieniu przepisów samorządowych ustaw ustrojowych i nie podlega zaskarżeniu do sądu administracyjnego. Wykonanie wskazań izby nie jest zabezpieczone żadną sankcją prawną, w związku z czym uchwałę kolegium izby podjętą w tym trybie uznaje się za środek nadzoru o charakterze informacyjno-doradczym ${ }^{23}$. Zatem, jak

19 Art. 240a ustawy z dnia 27 sierpnia 2009 r. o finansach publicznych stanowi, że w razie braku możliwości uchwalenia wieloletniej prognozy finansowej lub budżetu jednostki samorządu terytorialnego, zgodnie z zasadami określonymi w art. 242-244, oraz zagrożenia realizacji zadań publicznych przez jednostkę samorządu terytorialnego, kolegium regionalnej izby obrachunkowej wzywa jednostkę samorządu terytorialnego do opracowania i uchwalenia programu postępowania naprawczego oraz przedłożenia tego programu celem zaopiniowania do regionalnej izby obrachunkowej, w terminie 45 dni od dnia otrzymania wezwania. Organ stanowiący jednostki samorządu terytorialnego uchwala program postępowania naprawczego na okres nieprzekraczający trzech kolejnych lat budżetowych, z uwzględnieniem wymagań formalnych i ograniczeń związanych $\mathrm{z}$ realizacją programu postępowania naprawczego wskazanych $\mathrm{w}$ tym przepisie.

${ }^{20} \mathrm{Z}$ art. 240b ust. 1 zdanie pierwsze ustawy z dnia 7 października 1992 r. o regionalnych izbach obrachunkowych wynika, że w razie braku możliwości uchwalenia wieloletniej prognozy finansowej lub budżetu jednostki samorządu terytorialnego, zgodnie z zasadami określonymi w art. 242-244, budżet jednostki samorządu terytorialnego ustala regionalna izba obrachunkowa.

21 Zob. T. Dobek, Działalność regionalnych izb obrachunkowych..., s. 132.

22 J. Glumińska-Pawlic, Czy nadzór i kontrola nad gospodarka finansowa...

23 Z. Kmieciak, Rozstrzygnięcie nadzorcze regionalnej izby obrachunkowej, Państwo i Prawo 1995, z. 2, s. 38-39; Z. Kmieciak, Podstawa prawna i formy ingerencji nadzorczej regionalnej izby obrachunkowej, Samorząd Terytorialny 1995, nr 9, s. 42-51; zob. też postanowienie NSA z dnia 16 kwietnia 2002 r., II Sa/Wr 2151/00, Orzecznictwo Sądów Polskich 2003, z. 10, poz. 134; postanowienie NSA z dnia 21 lutego 2007 r., II GSK 299/06, LEX nr 326273; odmiennie M. Stahl, Glosa do postanowienia NSA z dnia 16 kwietnia 2002 r., II SA/Wr 2151/00, 
przyjęto w piśmiennictwie, kolegium izby, zwracając w swoim orzeczeniu uwagę na ten fakt, przyjmuje, że organ jednostki samorządu terytorialnego w podobnej sytuacji, mogącej wystąpić w przyszłości, nie popełni podobnego błędu' ${ }^{24}$.

Rozstrzygnięcia nadzorcze RIO podejmowane w formie uchwał kolegium kończą postępowanie uregulowane przepisami ustawy o regionalnych izbach obrachunkowych, K.p.a. ${ }^{25}$ oraz samorządowych ustaw ustrojowych i mogą być zaskarżone do Wojewódzkiego Sądu Administracyjnego (dalej: WSA) przez jednostkę samorządu terytorialnego, której dotyczą, z powodu niezgodności z prawem, w terminie 30 dni od dnia ich doręczenia ${ }^{26}$. Rozstrzygnięcia nadzorcze stają się prawomocne z upływem terminu do wniesienia skargi albo $z$ dniem oddalenia lub odrzucenia skargi przez sąd. Uzyskanie przez rozstrzygnięcie cechy prawomocności sprawia, że jest ono niewzruszalne, a zatem nie przysługuje wobec niego żaden środek zaskarżenia ${ }^{27}$.

\section{Właściwość rzeczowa RIO w zakresie działalności nadzorczej wobec jednostek samorządu terytorialnego}

Właściwość rzeczowa RIO w zakresie działalności nadzorczej wobec jednostek samorządu tery torialnego określona została w przepisach art. 11 ustawy o regionalnych izbach obrachunkowych. Zgodnie bowiem z art. 1 ust. 2 ab initio i in media tej ustawy izby sprawują nadzór nad działalnością jednostek samorządu terytorialnego w zakresie spraw finansowych określonych $\mathrm{w}$ art. 11 ust. 1.

Orzecznictwo Sądów Polskich 2003, z. 10, poz. 134, T. Woś, H. Knysiak-Molczyk, M. Romańska, w: Prawo o postępowaniu przed sądami administracyjnymi. Komentarz, red. T. Woś, Warszawa 2005, s. 78.

24 J. Glumińska-Pawlic, Czy nadzór i kontrola nad gospodarka finansowa...; R.P. Krawczyk, Ustawa o regionalnych izbach obrachunkowych a praktyka jej stosowania, Samorząd Terytorialny 1993, nr 12, s. 46.

25 J. Glumińska-Pawlic, Czy nadzór i kontrola nad gospodarka finansową...

26 Zob. art. 98 ustawy z dnia 8 marca 1990 r. o samorządzie gminnym, art. 85 ustawy z dnia 5 czerwca 1998 r. o samorządzie powiatowym oraz art. 86 ustawy z dnia 5 czerwca 1998 r. o samorządzie województwa.

27 J. Glumińska-Pawlic, Czy nadzór i kontrola nad gospodarka finansową... 
W świetle art. 11 ust. 1 ustawy o regionalnych izbach obrachunkowych w zakresie działalności nadzorczej właściwość rzeczowa RIO obejmuje uchwały i zarządzenia podejmowane przez organy jednostek samorządu terytorialnego $\mathrm{w}$ sprawach procedury uchwalania budżetu i jego zmian, budżetu i jego zmian, zaciągania zobowiązań wpływających na wysokość długu publicznego jednostek samorządu terytorialnego oraz udzielania pożyczek, zasad i zakresu przyznawania dotacji z budżetu jednostek samorządu terytorialnego, podatków i opłat lokalnych, do których mają zastosowanie przepisy ustawy Ordynacja podatkowa, absolutorium, wieloletniej prognozy finansowej i jej zmian. Ponadto w myśl ust. 2 i ust. 3 w przypadku niepodjęcia uchwały budżetowej przez organ stanowiący jednostkę samorządu terytorialnego do dnia 31 stycznia roku budżetowego izba ustala budżet tej jednostki w terminie do końca lutego roku budżetowego w zakresie zadań własnych oraz zadań zleconych. Zgodnie ze wskazaniem poczynionym w punkcie 2 opracowania izba ustala budżet jednostki samorządu terytorialnego w zakresie zadań własnych oraz zadań zleconych także $\mathrm{w}$ przypadku niezachowania przez tę jednostkę zasad określonych w art. 242-244 ustawy o finansach publicznych.

Powołane przepisy kształtują właściwość RIO w zakresie nadzoru wobec jednostek samorządu terytorialnego poprzez przedmiotowe wyliczenie podlegających temu nadzorowi kategorii aktów podejmowanych przez organy jednostek samorządu terytorialnego.

\section{Zakres właściwości rzeczowej RIO jako organów nadzoru wobec jednostek samorządu terytorialnego a pojęcie "spraw finansowych" na gruncie samorządowych ustaw ustrojowych}

Zakres właściwości RIO jako organów nadzoru wobec podmiotów samorządowych nie jest, zarówno w doktrynie, jak i w orzecznictwie, rozumiany jednolicie. Zasadniczy, a zarazem główny problem sprowadza się do charakteru katalogu spraw, które jako sprawy finansowe podlegają nadzorowi izb obrachunkowych, objętego przepisem art. 11 ust. 1 ustawy o regionalnych izbach obrachunkowych, a tym samym problem ten odnosi się do relacji zakresu wyliczenia wynikającego z tego przepisu do zakresu pojęcia "spraw finansowych" użytego w samorządowych ustawach ustrojowych i w Konstytucji RP. Obok bowiem wskazania przez 
ustawodawcę na zakres właściwości RIO w odniesieniu do nadzoru sprawowanego wobec jednostek samorządu terytorialnego w obszarze tym funkcjonuje pojęcie "spraw finansowych" jako wyznacznika kompetencji nadzorczych izb w analizowanym zakresie. Istotne jest wobec tego ustalenie stosunku przepisu wyliczającego sprawy, w których właściwość o charakterze nadzorczym przysługuje RIO wobec jednostek samorządu terytorialnego do przepisów samorządowych ustaw ustrojowych, które za ustawodawcą konstytucyjnym posługują się pojęciem „spraw finansowych", oraz do przyjmowanej ich interpretacji.

W literaturze przyjęto, że termin "sprawy finansowe" w rozumieniu konstytucyjnym, a tym samym także $\mathrm{w}$ rozumieniu samorządowych ustaw ustrojowych, nie pokrywa się z potocznym rozumieniem tych słów, ale stanowi on pojęcie niezależne, właściwe Konstytucji ${ }^{28}$. W najbardziej ogólnym ujęciu „sprawy finansowe” w rozumieniu konstytucyjnym oraz samorządowych ustaw ustrojowych obejmują kwestie związane ze stanowieniem budżetu jednostek samorządu terytorialnego, realizowane przez akty prawne kompleksowo obejmujące tę materię ${ }^{29}$. Ich podejmowanie wynika z kierowania samorządową gospodarką finansową przez organy jednostek samorządu terytorialnego, stanowiąc wyraz samodzielności i jawności działania. Łączy się ponadto z kumulowaniem lokalnych zasobów publicznych z prawnie określonych źródeł, do których należą subwencje ogólne i dotacje z budżetu państwa, oraz ich rozporządzaniem na cele publiczne ${ }^{30}$.

Jednocześnie w doktrynie można spotkać dwa przeciwstawne poglądy dotyczące charakteru wyliczenia spraw należących do właściwości RIO na gruncie art. 11 ust. 1 ustawy o regionalnych izbach obrachunkowych, a także trzeci pogląd, który można uznać za pogląd o charakterze pośrednim. Zgodnie z pierwszym z nich wskazany przez ustawodawcę katalog uchwał i zarządzeń jednostek samorządu terytorialnego

28 T. Dębowska-Romanowska, Regionalne izby obrachunkowe - nadzór zewnętrzny nad zarządzaniem finansowym w samorządzie i nad tworzeniem lokalnego prawa finansowego, w: Regionalne izby obrachunkowe. Charakterystyka..., s. 24.

29 A. Narowska, M. Pańczyk, M. Szybowska, Nadzór regionalnych izb obrachunkowych nad podstawowa jednostka samorządu terytorialnego - zagadnienia wybrane, Acta Universitas Lodziensis Folia Oeconomica 2012, t. 270, s. 107.

30 A. Narowska, M. Pańczyk, M. Szybowska, Nadzór regionalnych izb obrachunkowych..., s. 107. 
poddanych pod działalność nadzorczą RIO nie jest katalogiem zamkniętym $^{31}$. Skoro bowiem "tylko $\mathrm{w}$ art. 1 ust. 2 ustawy o regionalnych izbach obrachunkowych sprecyzowano, że izby te sprawują nadzór nad działalnością jednostek samorządu terytorialnego w zakresie spraw finansowych określonych $\mathrm{w}$ art. 11 ust. 1 tej ustawy, to przyjąć należy, że o tworzeniu tego katalogu decydowały kryteria wynikające z przemyślanego, a nie przypadkowego i dowolnego wyróżnienia spraw, które można uznać za finansowe" 32 . W świetle tych poglądów zakres pojęcia "spraw finansowych" wynikającego z samorządowych ustaw ustrojowych nie pokrywa się zatem z zakresem spraw, w których akty samorządowe poddane zostały nadzorowi RIO, określonych w art. 11 ust. 1 ustawy o regionalnych izbach obrachunkowych.

Druga grupa poglądów opiera się na uznaniu, że katalog spraw określonych $w$ art. 11 ust. 1 ustawy o regionalnych izbach obrachunkowych ma charakter zamknięty ${ }^{33}$. Takie podejście oznacza przyjęcie, że wymienione $\mathrm{w}$ art. 11 ust. 1 tej ustawy kategorie uchwał podejmowanych przez organy jednostek samorządu terytorialnego, podlegające badaniu przez izbę, wyczerpują pojęcie „sprawy finansowe" w rozumieniu odpowiednich przepisów samorządowych ustaw ustrojowych. A contrario wojewoda nie jest właściwy do orzekania w sprawie nieważności tych uchwał ${ }^{34}$. Zamknięty charakter katalogu spraw ujętych $\mathrm{w}$ analizowanym przepisie ustawy o regionalnych izbach obrachunkowych ujawnia się np. w odniesieniu do rozważenia możliwości objęcia nadzorem RIO aktów podejmowanych przez jednostki samorządu terytorialnego na gruncie przepisów

31 D. Laszczyk, Ustawa o regionalnych izbach obrachunkowych. Komentarz, Warszawa 2014 [wyd. el. LEX].

32 H. Kamieniecki, Uprawnienia nadzorcze regionalnych izb obrachunkowych $w$ orzecznictwie sądów administracyjnych z lat 2005-2007, Finanse Komunalne 2008, nr 12, s. 63.

33 Regionalne izby obrachunkowe. Charakterystyka...; P.W. Kryczko, w: Ustawa o samorzadzie gminnym. Komentarz, red. P. Chmielnicki, wyd. 4, Warszawa 2010 [wyd. el. LEX]; P. Walczak, Zamówienia wewnętrzne (in-house) jako forma powierzenia prowadzenia gospodarki komunalnej. Kompetencje nadzorcze wojewody i regionalnej izby obrachunkowej, Finanse Komunalne 2017, nr 4, s. 67; por. też Z. Kmieciak, M. Stahl, Akty nadzoru nad działalnością samorzqdu terytorialnego, Samorząd Terytorialny 2001, nr 1-2, s. 105; G. Jyż, w: G. Jyż, Z. Pławecki, A. Szewc, Ustawa o samorzadzie gminnym. Komentarz, wyd. 4, Warszawa 2012 [wyd. el. LEX].

34 P.W. Kryczko, w: Ustawa o samorządzie...; zob. też wyrok NSA z dnia 5 marca 2002 r., II SA/Ka 3232/2001, Orzecznictwo w Sprawach Samorządowych 2002, nr 3, poz. 88. 
ustawy Prawo zamówień publicznych ${ }^{35} \mathrm{~W}$ związku z procedurą powierzania dostaw, usług lub robót budowlanych ich podmiotom wewnętrznym, jako tzw. zamówień in-house ${ }^{36}$, na podstawie procedury udzielania zamówień z wolnej ręki. Udzielanie zamówień publicznych mogłoby zostać wpisane w zakres pojęcia "sprawy finansowe", o którym mowa w ustrojowych ustawach samorządowych, z tego względu, że, po pierwsze, stosowanie przepisów o zamówieniach publicznych przez jednostki sektora finansów publicznych, które zawierają umowy na dostawy, usługi lub roboty budowlane, zostało uznane za jedną z zasad systemu zamówień publicznych, co wynika z art. 44 ust. 4 ustawy o finansach publicznych. Po drugie, $\mathrm{z}$ art. 1 ust. 2 ustawy o regionalnych izbach obrachunkowych wynika kompetencja RIO do kontroli zamówień publicznych podmiotów objętych kognicją kontrolną, w tym jednostek samorządu terytorialnego, związków metropolitalnych, związków międzygminnych, stowarzyszeń gmin, stowarzyszeń gmin i powiatów, związków powiatów, związków powiatowo-gminnych, stowarzyszeń powiatów ${ }^{37}$. Wobec tego umieszczenie udzielenia zamówienia publicznego w zakresie pojęcia spraw objętych reglamentacją przepisów ustawy o finansach publicznych, a zatem - jak można uznać - właśnie spraw finansowych, a także wskazanie na kompetencje RIO do badania zamówień publicznych, mogłoby skłaniać do interpretacji, zgodnie z którą RIO pełni funkcję organu nadzoru nad zamawiającym w rozumieniu przepisów dotyczących zamówień publicznych, w tym w szczególności przepisu art. 144b ustawy Prawo zamówień publicznych, wskazującego na kompetencje nadzorcze w przypadku wątpliwości co do zasadności wykorzystania trybu zamówienia z wolnej ręki w odniesieniu do powierzenia przez jednostki samorządu terytorialnego zamówienia swojemu podmiotowi wewnętrznemu na zasadzie zamówień wewnętrznych ${ }^{38}$. Wniosek taki nie jest jednak uprawniony ze względu na wynikający z art. 11 ust. 1 ustawy o regionalnych izbach obrachunkowych

35 Ustawa z dnia 29 stycznia 2004 r. - Prawo zamówień publicznych, tekst jednolity: Dz. z 2019 r. poz. 1843 z późn. zm.

36 Zob. W. Baranowska-Zając, Wptyw implementacji przepisów nowych dyrektyw zamówieniowych Unii Europejskiej, dotyczacych zamówień wewnętrznych (in-house) udzielanych przez jednostki samorządu terytorialnego, na rozwój konkurencyjności i przedsiębiorczości na rynkach lokalnych, w: Wptyw prawa Unii Europejskiej na gospodarkę i samorząd terytorialny państw członkowskich, red. M. Ganczar, J. Król, M. Szewczak, Łódź 2016, s. 97-112.

37 P. Walczak, Zamówienia wewnętrzne (in-house) jako forma powierzenia..., s. 67.

38 Tamże. 
zamknięty charakter katalogu spraw, co do których izby dysponują prerogatywami nadzorczymi, jak również z uwagi na wyszczególnienie w art. 1 ust. 2 kompetencji kontrolnych, nie zaś nadzorczych izb w obszarze dotyczącym zamówień publicznych ${ }^{39}$. Nasuwa się wobec tego konstatacja, że choć w pewnych sytuacjach przyjęcie właściwości RIO w obszarze nadzoru, a tym samym przyjęcie szerszego rozumienia terminu „sprawy finansowe" jako ogólnego wyznacznika właściwości tych organów wydawałoby się rozwiązaniem bardziej odpowiednim systemowo i bardziej racjonalnym, to jednak jego zastosowanie nie jest możliwe ze względu na zachowanie prawnego charakteru nadzoru sprawowanego wobec jednostek samorządu terytorialnego.

Trzecie podejście do analizowanego problemu, które, w moim przekonaniu, można uznać za mające charakter pośredni pomiędzy dwiema wyżej wskazanymi grupami poglądów, opiera się na przekonaniu, że katalog siedmiu rodzajów aktów podlegających nadzorowi RIO jest katalogiem zamkniętym, jednak w poszczególnych rodzajach aktów mieszczą się różnego rodzaju uchwały i zarządzenia podejmowane przez organy jednostek samorządu terytorialnego ${ }^{40}$. Koncepcja taka stwarza jednak pewne niebezpieczeństwo niepoddawanego kontroli „otwierania” przedmiotowego katalogu, bowiem kategorie uchwał i zarządzeń, które miałyby się mieścić w poszczególnych rodzajach spraw wskazanych w treści art. 11 ust. 1 ustawy o regionalnych izbach obrachunkowych nie zostały nigdzie określone.

Także na gruncie orzecznictwa poglądy na analizowaną kwestię mają zróżnicowany charakter. Pogląd dotyczący zamkniętego charakteru katalogu spraw z art. 11 ust. 1 ustawy o regionalnych izbach obrachunkowych odzwierciedla wyrok WSA w Białymstoku z dnia 16 czerwca 2005 r. ${ }^{41} \mathrm{~W}$ powołanym wyroku WSA stwierdził, że: „z regulacji przepisu art. 86 ustawy o samorządzie gminnym wynika, że wojewoda jest organem nadzoru we wszystkich sprawach, które nie należą do kompetencji Prezesa Rady Ministrów ani do regionalnej izby obrachunkowej. Domniemanie kom-

39 Tamże, s. 68.

40 K. Sawicka, Nadzór regionalnych izb obrachunkowych nad uchwałami organów jednostek samorzadu terytorialnego, w: 15 lat funkcjonowania regionalnych izb obrachunkowych jako organów nadzoru i kontroli gospodarki finansowej jednostek samorządu terytorialnego, red. J. Małecki, R. Hauzer, Z. Janku, Poznań 2007, s. 71-72.

${ }^{41}$ Wyrok WSA w Białymstoku z dnia 16 czerwca 2005 r., II SA/Bk 476/05, LEX nr 173721. 
petencji wojewody powoduje, że pojęcia «spraw finansowych», o których mowa w art. 171 ust. 2 Konstytucji RP oraz w art. 86 u.s.g. [ustawy o samorządzie gminnym - W.B.-Z.], nie można interpretować rozszerzająco. W innym przypadku każde zadanie z zakresu kompetencji samorządu gminnego, którego realizacja rodzić będzie skutki finansowe, należałoby zaliczyć do "spraw finansowych»". Z tego względu ustawodawca konstruuje katalog spraw należących do właściwości rzeczowej regionalnej izby obrachunkowej, określając w art. 11 ust. 1 pkt 1-6 ww. ustawy przedmiot tych uchwał i zarządzeń podejmowanych przez organy jednostek samorządu terytorialnego, których legalność nadzoruje regionalna izba obrachunkowa. W kwestii wyczerpującego określenia zakresu spraw finansowych poddanych nadzorowi RIO na gruncie art. 11 ust. 1 ustawy o regionalnych izbach obrachunkowych wypowiedział się również NSA w wyroku z dnia 19 kwietnia 2000 r. ${ }^{42}$

Z kolei z wielu orzeczeń NSA wynika brak możliwości uznania katalogu kompetencji nadzorczych z art. 11 ust. 1 ustawy o regionalnych izbach obrachunkowych za katalog o charakterze zamkniętym. I tak w wyroku NSA z dnia 29 listopada 2007 r. ${ }^{43}$ wskazano, że katalog spraw poddanych nadzorowi RIO na podstawie art. 11 ustawy o regionalnych izbach obrachunkowych, choć można uznać za wyczerpujący w stosunku do podstawowych zagadnień finansowych (przede wszystkim budżetowych) samorządu terytorialnego, to nie jest on katalogiem całkowicie zamkniętym. Jednocześnie w cytowanym wyroku odniesiono się do uszczegółowienia jednej z kategorii spraw tam wskazanych, wyjaśniając, że przez pojęcie "spraw związanych z udzielaniem pożyczek" należy rozumieć wszystkie sprawy objęte uchwałami lub zarządzeniami organów jednostek samorządu terytorialnego mające za przedmiot pożyczkę (tj. jej udzielanie, rozkładanie na raty, umarzanie). Podobnie $w$ postanowieniu NSA z dnia 21 czerwca 2007 r. ${ }^{44}$ stwierdzono, że zawarty w art. 11 ust. 1 pkt 3 ustawy o regionalnych izbach obrachunkowych zwrot „udzielanie pożyczek” należy rozumieć jako obejmujący wszelkie zagadnienia związane z zaistnieniem bytu pożyczki, a więc także kwestię jej umorzenia ${ }^{45}$.

42 Wyrok NSA z dnia 19 kwietnia 2000 r., II SA 2298/99, niepubl.

43 Wyrok NSA z dnia 29 listopada 2007 r., II GSK 261/07, Orzecznictwo w Sprawach Samorządowych 2008, nr 3, poz. 73.

44 Postanowienie NSA z dnia 21 czerwca 2007 r., II GSK 76/07, LEX nr 338915.

45 Zob. też H. Kamieniecki, Uprawnienia nadzorcze regionalnych izb obrachunkowych..., s. 63. 
W wyroku z dnia 10 października 2007 r. ${ }^{46}$ NSA zaznaczył natomiast, że „w art. 11 ust. 1 ustawy o regionalnych izbach obrachunkowych znajduje się sformułowanie precyzujące zadania kontrolne regionalnych izb obrachunkowych, w odniesieniu do uchwał organów jednostek samorządu terytorialnego m.in. w sprawach procedury uchwalania budżetu i jego zmian (pkt 1) oraz budżetu i jego zmian (pkt 2). Ta regulacja nie może być utożsamiana $\mathrm{z}$ uściśleniem kompetencji nadzorczych regionalnych izb obrachunkowych, w szczególności przez ich ograniczenie do tylko tych enumeratywnie wymienionych uchwał organów jednostek samorządu terytorialnego. Zakres bowiem kompetencji nadzorczych regionalnych izb obrachunkowych określony został w innych przepisach - w tym w art. 171 ust. 2 Konstytucji RP".

Zaś w wyroku z dnia 21 czerwca 2005 r. ${ }^{47}$ NSA uznał, że "teza iż art. 11 ust. 1 ustawy o regionalnych izbach obrachunkowych nie może być utożsamiany z uściśleniem kompetencji nadzorczych regionalnych izb obrachunkowych, w szczególności przez ich ograniczenie do badania tylko tych enumeratywnie wymienionych uchwał organów jednostek samorządu terytorialnego, zakres bowiem kompetencji nadzorczych regionalnych izb obrachunkowych został określony w innych przepisach, $\mathrm{w}$ tym $\mathrm{w}$ art. 171 ust. 2 Konstytucji RP, zasługuje na aprobatę w stanie prawnym obowiązującym do 29 listopada 2003 r.".

Za wyraz takiego podejścia można uznać także wyrok WSA w Olsztynie z dnia 5 listopada 2009 r. ${ }^{48}$, w którym uznano, że "głównym wyznacznikiem rozgraniczającym kompetencje wojewody i regionalnej izby obrachunkowej jest pojęcie «sprawy finansowej». W związku z tym przy ustaleniu właściwości jednego z tych organów rozstrzygające znaczenie może mieć jedynie, czy przedmiot kontrolowanego aktu mieści się w tym pojęciu. Rozdysponowanie środków z funduszu celowego (funduszu ochrony środowiska i gospodarki wodnej) z pewnością spełnia kryteria sprawy finansowej".

W powołanym wyroku sąd odwołał się do ogólnego rozumienia pojęcia "spraw finansowych", nie definiując go, lecz zaliczając do tej kategorii

46 Wyrok NSA z dnia 10 października 2007 r., II GSK 151/07, LEX nr 399205.

47 Wyrok NSA z dnia 21 czerwca 2005 r., FSK 1750/04, Orzecznictwo w Sprawach Samorządowych 2007, nr 1, poz. 23.

48 Wyrok WSA w Olsztynie z dnia 5 listopada 2009 r., II SA/Ol 820/09, LEX nr 528026. 
konkretną sprawę, która nie mieści się w katalogu spraw umieszczonych w treści art. 11 ust. 1 ustawy o regionalnych izbach obrachunkowych.

Odmienne stanowisko $\mathrm{w}$ tej kwestii zajął NSA, który w wyroku z dnia 31 marca 2010 r. ${ }^{49}$ wskazał, że „brak jest jakichkolwiek podstaw do przyjęcia, że sprawa dotycząca danego funduszu celowego (art. 403 ustawy z dnia 27 kwietnia 2001 r. - Prawo ochrony środowiska - tekst jedn.: Dz. U. z 2008 r. Nr 25, poz. 150 z późn. zm.) stanowi sprawę finansową $w$ rozumieniu ustawy o regionalnych izbach obrachunkowych i że te właśnie organy są właściwe do sprawowania nadzoru nad uchwałami samorządu gminnego dotyczącymi tego typu spraw. Organem nadzoru $\mathrm{w}$ odniesieniu do uchwały $\mathrm{w}$ tej sprawie może być jedynie wojewoda, a następnie dopiero, $\mathrm{w}$ wyniku niekorzystnego dla gminy rozstrzygnięcia, przysługuje jej prawo do wniesienia skargi do sądu administracyjnego kwestionując[ej] właściwość wojewody do wydania rozstrzygnięcia nadzorczego".

Z kolei w wyroku z dnia 15 października 1999 r. ${ }^{50}$ za podlegające nadzorowi RIO uznano uchwały organów samorządu terytorialnego w sprawie przyznawania wynagrodzeń członkom zarządu, zaś w wyroku NSA $\mathrm{z}$ dnia 22 marca $2001 \mathrm{r} .^{51}$ - uchwałę rady gminy w kwestii regulacji diet radnych. Wskazane dwa rodzaje uchwał niewątpliwie nie mieszczą się w katalogu wynikającym z przepisu art. 11 ust. 1 ustawy o regionalnych izbach obrachunkowych.

Za wart odnotowania należy także uznać wyrok WSA w Łodzi $\mathrm{z}$ dnia 26 listopada 2015 r. ${ }^{52}$, w którym sąd ten nie podzielił argumentacji zarządu powiatu twierdzącego, że z uwagi na brak definicji pojęcia "spraw finansowych” kompetencje RIO należy ograniczyć do zjawisk i procesów pieniężnych i nie łączyć ich z zagadnieniami ustrojowymi, oraz orzekł na wniosek RIO o nieważności uchwały zarządu powiatu w przedmiocie zmian $\mathrm{w}$ budżecie powiatu $\mathrm{z}$ uwagi na to, że uchwałe podjął zarząd powiatu w składzie trzyosobowym w sytuacji, gdy zgodnie ze statutem powiatu w skład jego zarządu powinno wchodzić pięć osób. Sąd administracyjny zauważył, że zgodnie z art. 27 ust. 1 ustawy o samorządzie

49 Wyrok NSA z dnia 31 marca 2010 r., II OSK 85/10, LEX nr 601992.

50 Wyrok NSA z dnia 15 października 1999 r., III SA 757/99, LEX nr 40853.

51 Wyrok NSA z dnia 22 marca 2001 r., II SA/Ka 2606/00, Orzecznictwo w Sprawach Samorządowych 2002, nr 1, poz. 17; zob. też S. Kania, Glosa do wyroku NSA z dnia 22 marca 2001 r., II SA/Ka 2606/00, Samorząd Terytorialny 2002, nr 7-8, s. 143.

52 Wyrok WSA w Łodzi z dnia 26 listopada 2015 r., I SA/Łd 747/15, LEX nr 1944737. 
powiatowym rada powiatu wybiera zarząd $\mathrm{w}$ liczbie od trzech do pięciu osób, w tym starostę i wicestarostę, zaś liczbę członków zarządu określa się w statucie. Obowiązkiem rady powiatu jest zatem wybór in extenso zarządu powiatu jako organu wykonawczego. Wybór wszystkich osób wchodzących w skład tego organu, zgodnie z przyjętą w statucie ich liczbą, kończy procedurę wyboru zarządu. Dopiero tak ukształtowany zarząd jest uprawniony do podejmowania uchwa ${ }^{53}$, w tym zatem również uchwały dotyczącej wprowadzenia zmian w budżecie. Sąd uznał, że zaskarżona przez RIO uchwała nie była podjęta przez zarząd, lecz przez poszczególnych jego członków, bowiem zarząd nie został wybrany, a tym samym nie doszło do podjęcia uchwały o zmianie budżetu.

Argumentację WSA podzielił również NSA, który w wyroku z dnia 20 lutego 2018 r. oddalił skargę kasacyjną wniesioną przez zarząd powiatu ${ }^{54}$. NSA wskazał, że ustawa o samorządzie powiatowym ogranicza kompetencje nadzorcze RIO jedynie do spraw finansowych. Realizując w tym zakresie funkcję nadzorczą, izba jest jednak zobowiązana badać zgodność z prawem uchwał finansowych organów powiatu. Zdaniem NSA nie ulega wątpliwości, że badanie zgodności z prawem aktu powinno w pierwszej kolejności polegać na ustaleniu, czy nie został on wydany z naruszeniem przepisów kompetencyjnych i proceduralnych. Zatem, jak uznał NSA, badanie przez RIO, czy uchwała zarządu powiatu w sprawie zmian budżetu powiatu była wydana przez organ wybrany w sposób zgodny z przepisami ustawy o samorządzie powiatowym mieściło się w granicach kompetencji nadzorczych tego organu ${ }^{55}$. NSA nie podzielił argumentacji zarządu powiatu, że włączenie kwestii ustrojowych do postępowań nadzorczych prowadzonych przez RIO stanowi bezpodstawne rozszerzenie katalogu spraw należących do ich właściwości rzeczowej.

W analizowanej sprawie termin „sprawy finansowe” został więc ustalony poprzez uznanie, że nadzór RIO obejmuje wprawdzie uprawnienie do stwierdzenia nieważności uchwały o zmianie budżetu, lecz nie z uwagi na jej treść czy zakres, ale ze względu na uchybienia o charakterze ustrojowym zaistniałe przy jej podejmowaniu, tj. podjęcie jej przez zarząd w składzie ilościowym niezgodnym z postanowieniami statutu powiatu.

\footnotetext{
53 Uzasadnienie wyroku WSA w Łodzi z dnia 26 listopada 2015 r.

54 Wyrok NSA z dnia 20 lutego 2018 r., II GSK 1367/16, LEX nr 2462812.

55 Uzasadnienie wyroku NSA z dnia 20 lutego 2018 r.
} 
W praktyce stosowania prawa przez podmioty samorządowe także mamy do czynienia z szerszym podejściem do rozumienia zakresu właściwości nadzorczej RIO. Takie podejście zostało przyjęte $\mathrm{w}$ odniesieniu do uchwał podejmowanych na podstawie ustawy o utrzymaniu czystości i porządku w gminach ${ }^{56}$. Krajowa Rada Regionalnych Izb Obrachunkowych dnia 27 września 2012 r. podjęła uchwałę w sprawie objęcia nadzorem uchwał jednostek samorządu terytorialnego wydawanych na podstawie ustawy o utrzymaniu czystości i porządku w gminach $^{57}$. W oparciu o przedmiotową uchwałę izby uznały się za właściwe w obszarze sprawowania nadzoru nad rozstrzygnięciami jednostek samorządu terytorialnego, po pierwsze, w sprawie wyboru metody ustalania opłaty za gospodarowanie odpadami komunalnymi oraz ustalania stawki takiej opłaty, na podstawie art. 6k ust. 1 pkt 1 i art. 6j ustawy o utrzymaniu czystości i porządku w gminach, po drugie, w sprawie ustalenia stawki opłaty za pojemnik o określonej pojemności, co wynika z art. 6k ust. 1 pkt 2 ustawy o utrzymaniu czystości i porządku w gminach, po trzecie wreszcie, w odniesieniu do terminu, częstotliwości i trybu uiszczenia opłaty za gospodarowanie odpadami komunalnymi w oparciu o art. $61 \mathrm{ww}$. ustawy, a także w kwestii określania wzoru deklaracji o wysokości opłaty za gospodarowanie odpadami komunalnymi składanej przez właścicieli nieruchomości (art. 6n). Jednocześnie jednak we wszystkich rodzajach uchwał podejmowanych na podstawie ustawy o utrzymaniu czystości i porządku w gminach, a zatem także uchwał objętych wskazaną uchwałą Krajowej Rady Regionalnych Izb Obrachunkowych, za właściwy organ nadzoru uznał się jeden $\mathrm{z}$ wojewodó $\mathrm{w}^{58}$, choć następnie ostatecznie zaakceptował on przedmiotowe stanowisko Krajowej Rady Regionalnych Izb Obrachunkowych.

Taki stan rzeczy dowodzi niejednolitości rozumienia zakresu właściwości RIO w obszarze sprawowania nadzoru nad jednostkami samorządu terytorialnego. W kwestii kompetencji nadzorczej izb obrachunkowych we wskazanym obszarze negatywnie wypowiedział się jednak WSA w Olsztynie, który w wyroku z dnia 11 kwietnia 2013 r. ${ }^{59}$ uznał, że uchwa-

56 Ustawa z dnia 13 września 1996 r. o utrzymaniu czystości i porządku w gminach, tekst jednolity: Dz. U. z 2019 r. poz. 2010 z późn. zm.

57 Uchwała Krajowej Rady Regionalnych Izb Obrachunkowych z dnia 27 września 2012 r., Nr 10/2012.

58 Zob. R.P. Krawczyk, Efektywność i skuteczność nadzoru..., s. 8.

59 Wyrok WSA w Olsztynie z dnia 11 kwietnia 2013 r., II SA/Ol 137/13, LEX nr 1350150. 
ła w sprawie wzoru deklaracji o wysokości opłaty za gospodarowanie odpadami komunalnymi składanej przez właścicieli nieruchomości nie jest uchwałą organu gminy $\mathrm{w}$ sprawie finansowej w rozumieniu przepisów ustawy o regionalnych izbach obrachunkowych. Zdaniem sądu okoliczność, że do opłat za gospodarowanie odpadami komunalnymi stosuje się przepisy Ordynacji podatkowej nie przesądza o tym, iż sprawy dotyczące deklaracji o wysokości opłaty za gospodarowanie odpadami komunalnymi są sprawami, o których mowa w art. 11 ust. 1 pkt 5 ww. ustawy.

Mając na uwadze powyższe, należy dojść do wniosku, że zakres właściwości RIO w obszarze nadzoru sprawowanego przez ten organ wobec jednostek samorządu terytorialnego nie jest rozumiany jednolicie zarówno $\mathrm{w}$ doktrynie prawa, $\mathrm{w}$ orzecznictwie, jak i wreszcie w praktyce stosowania prawa. Taki stan rzeczy stwarza z kolei ryzyko niepewności w obszarze stosowania prawa przez organy jednostek samorządu terytorialnego oraz organy nadzorcze.

\section{Zakończenie}

W świetle obowiązujących samorządowych ustaw ustrojowych nadzór wykonywany przez RIO ograniczony został wyłącznie do spraw finansowych, a zatem ma charakter węższy od nadzoru premiera i wojewo$\mathrm{dy}^{60}$. Niezwykle istotne, choć - jak zostało wykazane powyżej - trudne do osiągnięcia w oparciu o obecnie obowiązujące regulacje prawne, jest właściwe rozgraniczenie kompetencji między wojewodów i RIO, które dawałoby pewność, że na tle stosowania prawa nie pozostają obszary możliwe do określenia jako „niczyje”. Jednocześnie brak precyzyjnego uregulowania rozdziału kompetencji nadzorczych między wojewodów a RIO i stosowanie różnych interpretacji, a tym samym różnego rozumienia zakresu kompetencji dwóch równoważnych organów nadzorczych powoduje, że w dalszym ciągu mamy do czynienia z niepewnością w zakresie kognicji nadzorczej ${ }^{61}$.

60 B. Dolnicki, w: Ustawa o samorzadzie gminnym. Komentarz, red. B. Dolnicki, wyd. 2, Warszawa 2018 [wyd. el. LEX].

${ }^{61}$ Por. R.P. Krawczyk, Efektywność i skuteczność nadzoru..., s. 7. 
Należy się skłonić ku przyjęciu stanowiska, że zawarty w art. 11 ust. 1 ustawy o regionalnych izbach obrachunkowych katalog spraw poddanych nadzorowi RIO ma charakter zamknięty, nadzór nad samorządem terytorialnym jest bowiem nadzorem prawnym, co oznacza, że podmioty sprawujące nadzór, środki nadzoru, przesłanki nadzoru powinny wyraźnie wynikać z przepisów prawa. Nie wydaje się zatem uprawnione stosowanie rozszerzającej interpretacji określenia "sprawy finansowe", o którym mowa w ustrojowych ustawach samorządowych, a wręcz wykładnia ta powinna mieć charakter zawężający. Za szerszą interpretacją zwrotu "sprawy finansowe" na gruncie przepisów o nadzorze wynikających z samorządowych ustaw ustrojowych aniżeli tylko językowa jego wykładnia wynikająca z brzmienia art. 11 ust. 1 ustawy o regionalnych izbach obrachunkowych, wskazującego na właściwość rzeczową RIO w sferze nadzoru, przemawiać by mogły argumenty logiczne i systemowe. Podstawy właściwości RIO w zakresie nadzoru można jednak zmieniać czy rozszerzać w drodze zmiany ustawy, a konkretnie art. 11 ust. 1 ustawy o regionalnych izbach obrachunkowych na zasadzie rozszerzenia czy też uszczegóławiania wynikającego z jego przepisów katalogu spraw uznanych za sprawy finansowe, a tym samym podlegające nadzorowi RIO. Należy w związku z tym postulować zwracanie przez ustawodawcę większej uwagi na dostosowanie katalogu z art. 11 ust. 1 ustawy o regionalnych izbach obrachunkowych do zmian w przepisach dotyczących instytucji poddawanych pod nadzór organów sprawujących nadzór wobec jednostek samorządu terytorialnego, tak aby zapewnić większą adekwatność przedmiotową sprawowania tego nadzoru oraz spójność z innymi przepisami systemu prawa. Dotyczy to np. przepisów ustawy o finansach publicznych czy przepisów odnoszących się do zamówień publicznych, zwłaszcza w odniesieniu do nadzoru wobec udzielania zamówień wewnętrznych $\mathrm{w}$ przewidzianym ku temu trybie, który z racji niedokonania odpowiednich zmian $w$ treści art. 11 ust. 1 ustawy o regionalnych izbach obrachunkowych nie może być poddany pod właściwość nadzorczą RIO, choć przedmiotowo oraz systemowo nadzór tego właśnie organu byłby bardziej adekwatny niż nadzór sprawowany przez wojewodę.

Celem wyeliminowania wątpliwości należałoby rozważyć zamieszczenie przez ustawodawcę $\mathrm{w}$ treści przepisów samorządowych ustaw ustrojowych wskazujących na RIO jako organy sprawujące nadzór wobec jednostek samorządu terytorialnego w wyspecjalizowanym jedynie obszarze, spraw finansowych - odwołania do rozumienia tego pojęcia 
określonego za pomocą wyliczenia wynikającego z art. 11 ust. 1 ustawy o regionalnych izbach obrachunkowych. W państwie demokratycznym bowiem zarówno zakres przedmiotowy nadzoru, jak i jego podmiot nie powinny być ustalane na podstawie domniemań ${ }^{62}$, poprzez stosowanie analogii ${ }^{63}$ czy też w związku z rozstrzyganiem sporów kompetencyjnych. Należy pamiętać, że sprawowanie nadzoru i kontroli nad prowadzeniem gospodarki finansowej dokonywane jest $\mathrm{w}$ interesie ochrony porządku prawnego ustanowionego przez państwo ${ }^{64}$.

\section{Bibliografia}

\section{Źródła}

\section{Akty prawne}

Konstytucja Rzeczypospolitej Polskiej z dnia 2 kwietnia 1997 r., Dz. U. poz. 483 z późn. zm.

Uchwała Krajowej Rady Regionalnych Izb Obrachunkowych z dnia 27 września 2012 r., Nr 10/2012.

Ustawa z dnia 8 marca 1990 r. o samorządzie gminnym, tekst jednolity: Dz. U. z 2020 r. poz. 713.

Ustawa z dnia 7 października 1992 r. o regionalnych izbach obrachunkowych, tekst jednolity: Dz. U. z 2019 r. poz. 2137.

Ustawa z dnia 13 września 1996 r. o utrzymaniu czystości i porządku w gminach, tekst jednolity: Dz. U. z 2019 r. poz. 2010 z późn. zm.

Ustawa z dnia 5 czerwca 1998 r. o samorządzie powiatowym, tekst jednolity: Dz. U. z 2020 r. poz. 920.

Ustawa z dnia 5 czerwca 1998 r. o samorządzie województwa, tekst jednolity: Dz. U. z 2019 r. poz. 512 z późn. zm.

Ustawa z dnia 29 stycznia 2004 r. - Prawo zamówień publicznych, tekst jednolity: Dz. z 2019 r. poz. 1843 z późn. zm.

Ustawa z dnia 27 sierpnia 2009 r. o finansach publicznych, tekst jednolity: Dz. U. z 2019 r. poz. 869 z późn. zm.

62 Tamże, s. 8.

63 Regionalne izby obrachunkowe. Charakterystyka...

64 P.W. Kryczko, w: Ustawa o samorzadzie gminnym. Komentarz, red. P. Chmielnicki, wyd. 4, Warszawa 2010 [wyd. el. LEX]; T. Dębowska-Romanowska, Prawo finansowe - część konstytucyjna wraz z częścią ogólnq, Warszawa 2010, s. 118. 


\section{Orzecznictwo}

Postanowienie NSA z dnia 16 kwietnia 2002 r., II Sa/Wr 2151/00, Orzecznictwo Sądów Polskich 2003, z. 10, poz. 134.

Postanowienie NSA z dnia 21 lutego 2007 r., II GSK 299/06, LEX nr 326273.

Postanowienie NSA z dnia 21 czerwca 2007 r., II GSK 76/07, LEX nr 338915.

Wyrok NSA z dnia 15 października 1999 r., III SA 757/99, LEX nr 40853.

Wyrok NSA z dnia 19 kwietnia 2000 r., II SA 2298/99, niepubl.

Wyrok NSA z dnia 22 marca 2001 r., II SA/Ka 2606/00, Orzecznictwo w Sprawach Samorządowych 2002, nr 1, poz. 17.

Wyrok NSA z dnia 5 marca 2002 r., II SA/Ka 3232/01, Orzecznictwo w Sprawach Samorządowych 2002, nr 3, poz. 88.

Wyrok NSA z dnia 21 czerwca 2005 r., FSK 1750/04, Orzecznictwo w Sprawach Samorządowych 2007, nr 1, poz. 23.

Wyrok NSA z dnia 10 października 2007 r., II GSK 151/07, LEX nr 399205.

Wyrok NSA z dnia 29 listopada 2007 r., II GSK 261/07, Orzecznictwo w Sprawach

Samorządowych 2008, nr 3, poz. 73.

Wyrok NSA z dnia 31 marca 2010 r., II OSK 85/10, LEX nr 601992.

Wyrok NSA z dnia 20 lutego 2018 r., II GSK 1367/16, LEX nr 2462812.

Wyrok WSA w Białymstoku z dnia 16 czerwca 2005 r., II SA/Bk 476/05, LEX nr 173721.

Wyrok WSA w Olsztynie z dnia 5 listopada 2009 r., II SA/Ol 820/09, LEX nr 528026.

Wyrok WSA w Olsztynie z dnia 11 kwietnia 2013 r., II SA/Ol 137/13, LEX nr 1350150.

Wyrok WSA w Łodzi z dnia 26 listopada 2015 r., I SA/Łd 747/15, LEX nr 1944737.

\section{Literatura}

Baranowska-Zając W., Wptyw implementacji przepisów nowych dyrektyw zamówieniowych Unii Europejskiej, dotyczacych zamówień wewnętrznych (in-house) udzielanych przez jednostki samorządu terytorialnego, na rozwój konkurencyjności i przedsiębiorczości na rynkach lokalnych, w: Wptyw prawa Unii Europejskiej na gospodarkę i samorząd terytorialny państw członkowskich, red. M. Ganczar, J. Król, M. Szewczak, Łódź 2016.

Dębowska-Romanowska T., Regionalne izby obrachunkowe - nadzór zewnętrzny nad zarzadzaniem finansowym w samorzadzie i nad tworzeniem lokalnego prawa finansowego, w: Regionalne izby obrachunkowe. Charakterystyka ustrojowa i komentarz do ustawy, red. M. Stec, Warszawa 2010.

Dobek T., Dziatalność regionalnych izb obrachunkowych w 2016 r. Omówienie Sprawozdania Krajowej Rady Regionalnych Izb Obrachunkowych złożonego do Sejmu i Senatu Rzeczypospolitej Polskiej, Finanse Komunalne 2017, t. 24, nr 7-8. 
Dolnicki B., w: Ustawa o samorządzie gminnym. Komentarz, red. B. Dolnicki, Warszawa 2016.

Dolnicki B., w: Ustawa o samorzadzie gminnym. Komentarz, red. B. Dolnicki, wyd. 2, Warszawa 2018 [wyd. el. LEX].

Glumińska-Pawlic J., Czy nadzór i kontrola nad gospodarka finansowa jednostek samorządu terytorialnego ograniczaja ich samodzielność?, w: Samorząd - Finanse - Nadzór i kontrola. XX-lecie Regionalnych Izb Obrachunkowych, red. R.P. Krawczyk, M. Stec, Warszawa 2013 [wyd. el. LEX].

Izdebski H., Samorząd terytorialny. Podstawy ustroju i działalności, wyd. 3, Warszawa 2014.

Jyż G., w: G. Jyż, Z. Pławecki, A. Szewc, Ustawa o samorządzie gminnym. Komentarz, wyd. 4, Warszawa 2012 [wyd. el. LEX].

Kamieniecki H., Uprawnienia nadzorcze regionalnych izb obrachunkowych w orzecznictwie sądów administracyjnych z lat 2005-2007, Finanse Komunalne 2008, t. 15, nr 12.

Kania S., Glosa do wyroku NSA z dnia 22 marca 2001 r., II SA/Ka 2606/00, Samorząd Terytorialny 2002, nr 7-8.

Kmieciak Z., Rozstrzygnięcie nadzorcze regionalnej izby obrachunkowej, Państwo i Prawo 1995, z. 2.

Kmieciak Z., Podstawa prawna i formy ingerencji nadzorczej regionalnej izby obrachunkowej, Samorząd Terytorialny 1995, nr 9.

Kmieciak Z., Stahl M., Akty nadzoru nad dziatalnością samorządu terytorialnego, Samorząd Terytorialny 2001, nr 1-2.

Krawczyk R.P., Efektywność i skuteczność nadzoru nad samorządem terytorialnym a uwarunkowania prawno-faktyczne, Finanse Komunalne 2014, t. 21, nr 10.

Krawczyk R.P., Ustawa o regionalnych izbach obrachunkowych a praktyka jej stosowania, Samorząd Terytorialny 1993, nr 12.

Kryczko P.W., w: Ustawa o samorządzie gminnym. Komentarz, red. P. Chmielnicki, wyd. 4, Warszawa 2010 [wyd. el. LEX].

Laszczyk D., Ustawa o regionalnych izbach obrachunkowych. Komentarz, Warszawa 2014 [wyd. el. LEX].

Leoński Z., System nadzoru nad samorządem terytorialnym w świetle ustawy z 8 marca 1990 r., Państwo i Prawo 1990, z. 12.

Narowska A., Pańczyk M., Szybowska M., Nadzór regionalnych izb obrachunkowych nad podstawowa jednostka samorzadu terytorialnego - zagadnienia wybrane, Acta Universitas Lodziensis. Folia Oeconomica 2012, t. 270.

Sawicka K., Nadzór regionalnych izb obrachunkowych nad uchwałami organów jednostek samorzadu terytorialnego, w: 15 lat funkcjonowania regionalnych izb obrachunkowych jako organów nadzoru i kontroli gospodarki finansowej jednostek samorządu terytorialnego, red. J. Małecki, R. Hauzer, Z. Janku, Poznań 2007. 
Stahl M., Glosa do postanowienia NSA z dnia 16 kwietnia 2002 r., II SA/Wr 2151/00, Orzecznictwo Sądów Polskich 2003, z. 10, poz. 134.

Regionalne izby obrachunkowe. Charakterystyka ustrojowa i komentarz do ustawy, red. M. Stec, Warszawa 2010 [wyd. el. LEX].

Storczyński J., Nadzór regionalnej izby obrachunkowej nad samorządem terytorialnym, Bydgoszcz-Chorzów 2006.

Walczak P., Zamówienia wewnętrzne (in-house) jako forma powierzenia prowadzenia gospodarki komunalnej. Kompetencje nadzorcze wojewody i regionalnej izby obrachunkowej, Finanse Komunalne 2017, t. 24, nr 4.

Woś T., Knysiak-Molczyk H., Romańska M., w: Prawo o postępowaniu przed sądami administracyjnymi. Komentarz, red. T. Woś, Warszawa 2005.

\section{Streszczenie}

RIO zostały przewidziane w polskim systemie prawa jako jeden z organów nadzoru wobec jednostek samorządu terytorialnego. Wykonują one jednak ten nadzór w ściśle określonych granicach przedmiotowych - „w zakresie spraw finansowych". Pojęcie „spraw finansowych" stanowi kryterium odróżniające nadzór sprawowany przez RIO i przez wojewodów. Zakreśla tym samym granice właściwości rzeczowej RIO w obszarze nadzoru nad jednostkami samorządu terytorialnego. Pojęcie to nie zostało jednak w sposób jednoznaczny zdefiniowane w przepisach prawa. Ustalenie znaczenia terminu "sprawy finansowe", a ściślej - sposobu rozumienia jego zakreślenia dokonanego przez ustawodawcę - było przedmiotem uwagi doktryny i orzecznictwa sądów administracyjnych. Spójna koncepcja w tym obszarze nie została jednak, jak dotąd, wypracowana. Tymczasem brak precyzyjnego uregulowania rozdziału kompetencji nadzorczych między wojewodów a RIO i stosowanie w tej kwestii rozmaitych, rozbieżnych interpretacji, a tym samym różnego rozumienia zakresu kompetencji dwóch równoważnych organów nadzoru, powoduje niepewność prawa w odniesieniu do zakresu kognicji nadzorczej. Z tych względów podjęto próbę uporządkowania przedmiotowej problematyki oraz wypracowania postulatów de lege ferenda.

Słowa kluczowe: regionalna izba obrachunkowa, nadzór, jednostki samorządu terytorialnego, właściwość rzeczowa, sprawy finansowe 


\section{THE RATIONE MATERIAE COMPETENCE OF REGIONAL ACCOUNTING CHAMBERS AS SUPERVISORY AUTHORITIES OF LOCAL SELF- GOVERNMENT UNITS AND THE SCOPE OF THE CONCEPT OF 'FINANCIAL MATTERS' - AN ATTEMPT TO SCRUTINIZE THE ISSUES}

\section{Sum mary}

In the Polish legal system the regional accounting chambers have been envisaged as one of the supervisory bodies over the local self-government units. However, they execute this supervision within the strictly defined subject limits - 'in financial matters'. The concept of 'financial matters' is a criterion that differentiates supervision exercised by the regional accounting chambers and voivodship governors. Thus, it outlines the boundaries of the regional accounting chambers' ratione materiae competences in the scope of supervision of the local self-government units. However, this concept has not been clearly defined in law. Determination of the meaning of the 'financial matters' term, or more precisely - the way of understanding its definition made by the legislator - was the subject matter of the legal doctrine and judicial decisions of the administrative courts. A consistent concept in this area has not been developed yet. Meanwhile, the lack of precise regulation of the division of supervisory powers between the voivodship governors and regional accounting chambers, as well as the use of the various divergent interpretations in this matter and thus a different understanding of the scope of competences of the two equivalent supervisory bodies, causes legal uncertainty regarding the scope of supervisory recognition. For these reasons, the article was formulated as an attempt to scrutinize the issues and to develop de lege ferenda demands.

Key words: regional accounting chamber, supervision, local self-government units, ratione materiae competence, financial matters

\section{ПРЕДМЕТНАЯ КОМПЕТЕНЦИЯ РЕГИОНАЛЬНЫХ СЧЕТНЫХ \\ ПАЛАТ КАК НАДЗОРНЫХ ОРГАНОВ В ОТНОШЕНИИ \\ К ЕДИНИЦАМ ТЕРРИТОРИАЛЬНОГО САМОУПРАВЛЕНИЯ И СФЕРА ПРИМЕНЕНИЯ ПОНЯТИЯ «ФИНАНСОВЫЕ ВОПРОСЫ» - ПОПЫТКА УПОРЯДОЧЕНИЯ ПРОБЛЕМАТИКИ}

Резюме

Региональные счетные палаты предусмотрены в польской правовой системе как один из надзорных органов в отношении к единицам территориального самоуправления. Однако они осуществляют этот надзор в строго 
определенных предметных пределах - «по финансовым вопросам». Понятие «финансовые вопросы» является критерием, который отличает надзор, осуществляемый Региональными счетными палатами и воеводами. Таким образом, оно очерчивает границы предметной компетенции Региональных счетных палат в области надзора за единицами территориального самоуправления. Однако это понятие не было четко определено в правовых нормах. Определение значения термина «финансовые вопросы», а точнее - способ понимания его определения законодателем - было предметом внимания доктрины и судебной практики административных судов. Однако когерентная концепция в этой области еще не разработана. Между тем, отсутствие точного регулирования распределения надзорных полномочий между воеводами и Региональными счетными палатами и использование различных расходящихся толкований в этом вопросе, и, следовательно, различное понимание сферы компетенций двух эквивалентных надзорных органов, вызывает юридическую неопределенность в отношении к сфере полномочий органов в области надзора. По этим причинам была предпринята попытка упорядочить предметную проблематику и разработать постулаты de lege ferenda.

Ключевые слова: Региональная счетная палата, надзор, единицы территориального самоуправления, предметная компетенция, финансовые вопросы 
